\title{
AWARENESS OF PORCINE HELMINTHIASIS AND THE PREVALENT FARM MANAGEMENT OPERATIONS AMONG SMALLHOLDER PIG FARMERS IN THE FREE STATE
}

\author{
Nwafor, I. C. ${ }^{1}$, Roberts, H. $^{2}$ and Fourie, P. J. ${ }^{3}$ \\ Correspondence author: I. C. Nwafor. Email: nwaforifeomac@yahoo.com
}

\begin{abstract}
Porcine helminthiasis and its zoonotic tendencies can lead to considerable loss of productivity and food security, especially in subsistence farming systems. Using open- and closed-ended questionnaires, this study was designed to ascertain the level of awareness of smallholder pig farmers in the selected districts of the Free State Province of South Africa to porcine helminthiasis and to gather information on the various pre- and post-slaughter practices prevalent in these areas. Results show that intestinal helminths emerged as the most common herd health problem (65.2\%). There was a high rate of ignorance towards anthelmintic resistance and zoonoses among farmers. Similarly, 53.3\% of respondents described the cost of anthelmintics as "expensive". A high positive correlation $(P<0.01)$ between some farming practices exist. Furthermore, $73.9 \%$ of respondents do not slaughter their pigs in an abattoir due to the high cost of slaughter and transportation, long distances to the abattoir, and small scale of production. Moreover, 50.0\% of the farmers reported that their pig production enterprise was not profitable or viable. The information from this study may be used as baseline knowledge to help formulate the development of extension programmes for sustainable pig rearing and pork production, especially among smallholder farmers.
\end{abstract}

Keywords: Anthelmintic resistance, Extension programmes, Porcine helminthiasis, Smallholder pig farmers, Zoonoses

\section{INTRODUCTION}

The consumption of pork and pork products play a vital role in the nutrition and health status of its consumers, especially in developing countries. In South Africa, pork is the third highest produced meat (Department of Agriculture, Forestry and Fisheries (DAFF), 2012), and the domestic demand for pork increased by 24\% between 2007 and 2015 (South African Government (SAG), 2015). However, porcine helminthiasis is a major constraint to profitable pig production. This infection can lead to considerable loss of productivity, which in turn threatens food security, especially in subsistence farming systems. The intensive use of anthelmintics has resulted in a substantial anthelmintic failure due to increasing incidences of resistance in some worm species (Bakunzi, 2003; Coles et al, 2006; European Medicines Agency (EMA), 2017). A review of literature revealed that in the Free State Province, insufficient information is available regarding the predisposing factors, prevention, control, and consequences of porcine helminthiasis, zoonosis and anthelmintic administration.

\footnotetext{
${ }^{1}$ Doctoral candidate, Department of Agriculture, Central University of Technology, Bloemfontein, South Africa, Email: nwaforifeomac@yahoo.com

${ }^{2}$ Senior Lecturer, Department of Life Sciences, Central University of Technology, Bloemfontein, South Africa, Email: robertsh@cut.ac.za

${ }^{3}$ Associate Professor, Department of Agriculture, Central University of Technology, Bloemfontein, South Africa, Email: pfourie@cut.ac.za
} 
It was in this context that a questionnaire which aims to form a baseline information to determine smallholder pig farmers' knowledge and awareness in relation to the above issues was designed. The feedback from this study is intended to help develop far-reaching and effective extension programmes for sustainable pork husbandry and production initiatives, especially among smallholder farmers.

\subsection{Study objectives}

This study aimed to ascertain, inter alia, the number of viable small-scale pig production units in the study area; pre- and post-slaughter practices; prevailing on-farm management practices; hygiene standards on farms; vaccination and deworming regimes; knowledge of porcine helminthiasis and zoonotic helminths; anthelmintic administration and withdrawal; and drug resistance.

\section{METHODOLOGY}

\subsection{Research design}

This study was designed to use a mixed-methods questionnaire approach by administering both open- and closed-ended semi-structured questions to respondents as recommended by Creswell and Creswell (2003). The questionnaires were randomly issued to 46 smallholder pig farmers in selected districts of the Free State Province. The experimental sites were chosen because of the large population of viable smallholder pig production units sited in these districts and the number of respondents was based on the number of reachable smallholder pig farmers in the research sites during the study period. The questions were designed to address the objectives of the study which has been preceded by an intensive literature review.

\subsection{Questionnaire distribution}

To facilitate speedy distribution of the questionnaires to smallholder pig farmers within the four selected districts (Mangaung Metropolitan (Motheo), Fezile Dabi (Northern Free State), Thabo Mofutsanyana, and Lejweleputswa - Figure 1), the Free State piggery database was obtained from the Department of Agriculture at Glen. The database contained the names of farmers, their contact numbers, farm locations, scale of production, and the details of the designated extension officers. The questionnaires were both interviewer-administered and selfadministered between the months of September and December in 2016. Extension officers were used as local language interpreters in most cases.

\subsection{Statistical analyses}

Responses from the respondents were arranged, summarised, coded and transferred to the computer software programme, Statistical Package for Social Sciences (SPSS) version 22. The data from the questionnaires were further statistically analysed to obtain frequencies and percentage values. Graphical representations and simple correlations between variables were produced. 


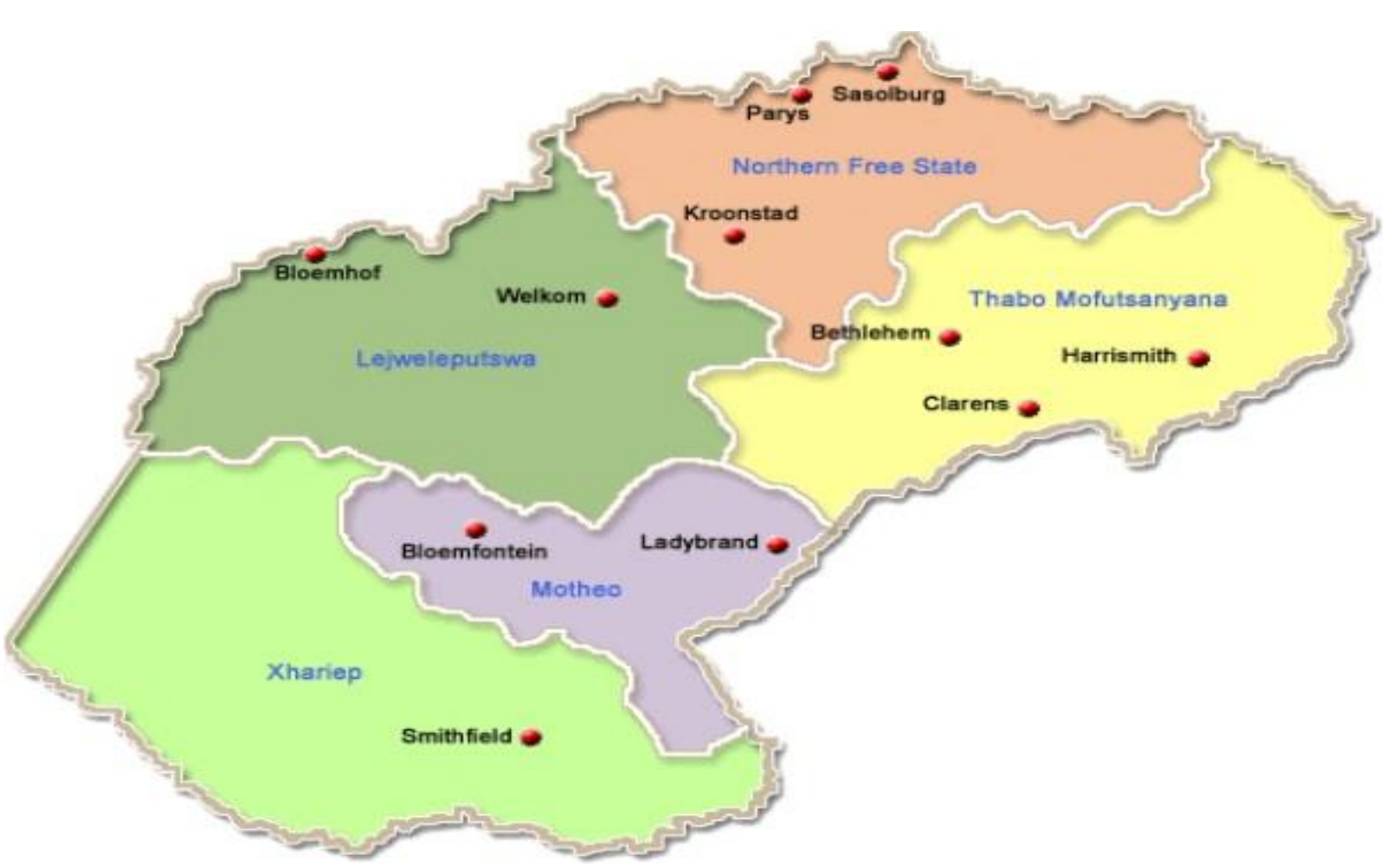

Figure 1: Map of selected districts in the Free State Province of South Africa

\section{RESULTS AND DISCUSSION}

Results in Table 1 show that Mangaung Metropolitan had the highest number of respondents at $58.7 \%$, while Lejweleputswa district recorded the lowest rate at 6.5\%. Fezile Dabi (Northern Free State) and Thabo Mofutsanyana districts had an equal respondent rate at $17.4 \%$ of the total sampled population. The highest response frequency was recorded for Mangaung Metropolitan (Motheo) district due to the larger number of smallholder pig farmers in this region and accessibility logistics. All the respondents were black farmers who were mostly between the ages of 51 and 60 years $(34.8 \%)$. Furthermore, males accounted for more than half $(69.6 \%)$ of the respondents. The majority $(60.9 \%)$ possessed little or no level of formal education and could therefore hardly read or write in English or their local languages. Their arithmetic ability was generally poor, which concurred with the findings of an earlier study by Maphalla and Salman (2002). Similar findings were also reported in a study conducted in the Gauteng Province by Matabane et al (2015), who recorded a very low percentage of youth participation in pig farming, a male dominated enterprise, and that there was a dearth of basic skills due to lack of education amongst smallholder pig farmers in the region. In the current study, very few $(6.5 \%)$ of the respondents had been in the pig farming industry for more than 20 years, with an average of between 10 and 15 years of farming experience, while $39.1 \%$ of the responding farmers had not exceeded five years in this industry. It was also revealed that $80.4 \%$ of the smallholder pig farmers had exotic breeds of pigs and farmed mostly on a fulltime basis. 
Table 1: Demographics of the farmers and farming details $(n=46)$

\begin{tabular}{|c|c|c|c|}
\hline Factor & Variable & $\begin{array}{l}\text { Response } \\
\text { frequency }\end{array}$ & Percentage (\%) \\
\hline \multirow{4}{*}{ Farm location } & MM & 27 & 58.7 \\
\hline & FD & 8 & 17.4 \\
\hline & TM & 8 & 17.4 \\
\hline & $\mathrm{LJ}$ & 3 & 6.5 \\
\hline \multirow{2}{*}{ Gender } & Male & 32 & 69.6 \\
\hline & Female & 14 & 30.4 \\
\hline \multirow{6}{*}{ Age of farmer (years) } & $21-30$ & 1 & 2.2 \\
\hline & $31-40$ & 4 & 8.7 \\
\hline & $41-50$ & 12 & 26.1 \\
\hline & $51-60$ & 16 & 34.8 \\
\hline & $61-70$ & 10 & 21.7 \\
\hline & $71-80$ & 3 & 6.5 \\
\hline \multirow{4}{*}{ Level of education } & Uneducated & 6 & 13.0 \\
\hline & Below matric & 28 & 60.9 \\
\hline & Undergraduate & 8 & 17.4 \\
\hline & Graduate & 4 & 8.7 \\
\hline \multirow{5}{*}{$\begin{array}{l}\text { Years of farming } \\
\text { experience }\end{array}$} & $0-5$ & 23 & 50.0 \\
\hline & $6-10$ & 5 & 10.9 \\
\hline & $11-15$ & 15 & 32.6 \\
\hline & $16-20$ & 2 & 4.3 \\
\hline & $21-25$ & 1 & 2.2 \\
\hline \multirow{5}{*}{$\begin{array}{l}\text { Years in pig farming } \\
\text { enterprise }\end{array}$} & $0-5$ & 18 & 39.1 \\
\hline & $6-10$ & 4 & 8.7 \\
\hline & $11-15$ & 15 & 32.6 \\
\hline & $16-20$ & 6 & 13.0 \\
\hline & $21-25$ & 3 & 6.5 \\
\hline \multirow{4}{*}{ Type of pig breed } & Exotic & 37 & 80.4 \\
\hline & Indigenous & 5 & 10.9 \\
\hline & Exotic X Indigenous & 2 & 4.3 \\
\hline & No idea & 2 & 4.3 \\
\hline \multirow{2}{*}{ Farming time } & Full time & 28 & 60.9 \\
\hline & Part time & 18 & 39.1 \\
\hline
\end{tabular}

MM: Mangaung Metropolitan (Motheo); FD: Fezile Dabi (Northern Free State); TM: Thabo Mofutsanyana; LJ: Lejweleputswa.

Exotic pig breeds: Large White, Landrace, Duroc, Large Black, etc.

Indigenous pig breeds: Kolbroek and Windsnyer

In Table 2, correlations between farm size (in hectares) and number of pigs per enterprise were highly positive $(\mathrm{P}<0.01, \mathrm{r}=0.972)$, with $54.3 \%$ of participants farming on $0-5$ ha of land. Most of the farmers (45.7\%) owned 5-10 pigs at the time of the study. This suggests the potential for increased production if sufficiently large expanses of land area were available to the farmers. Similarly, positive correlations $(\mathrm{P}<0.01, \mathrm{r}=0.623)$ existed between the type of farming methods and the management systems that were practised by the farmers. Moreover, $71.1 \%$ of respondents practised a semi-intensive farming system where animals foraged for food outside 
their stalls, while a very high proportion $(87.0 \%)$ of the farmers in the sample engaged in continuous flow-barn management practices. In an earlier study, Krecek et al (2004) reported that $25 \%$ of pigs in South Africa were free-ranging and owned by resource-poor farmers. A lower positive correlation $(\mathrm{P}<0.05, \mathrm{r}=0.342)$ was demonstrated between farm size and management practice, and between number of pigs and management practice in this study.

Table 2: Correlations between independent on-farm practices

\begin{tabular}{|l|c|c|c|c|}
\hline $\begin{array}{l}\text { Independent } \\
\text { variables }\end{array}$ & $\begin{array}{c}\text { Farm } \\
\text { size (ha) }\end{array}$ & $\begin{array}{c}\text { Number of } \\
\text { pigs }\end{array}$ & $\begin{array}{c}\text { Type of } \\
\text { farming } \\
\text { method }\end{array}$ & $\begin{array}{c}\text { Type of } \\
\text { management } \\
\text { system }\end{array}$ \\
\hline Farm size (Ha) & 1.000 & $0.972^{* *}$ & $0.760^{* *}$ & $0.342^{*}$ \\
\hline Number of pigs & $0.972^{* *}$ & 1.000 & $0.775^{* *}$ & $0.370^{*}$ \\
\hline $\begin{array}{l}\text { Type of farming } \\
\text { method }\end{array}$ & $0.760^{* *}$ & $0.775^{* *}$ & 1.000 & $0.623^{* *}$ \\
\hline $\begin{array}{l}\text { Type of } \\
\text { management system }\end{array}$ & $0.342^{*}$ & $0.370^{*}$ & $0.623^{* *}$ & 1.000 \\
\hline
\end{tabular}

** Correlation is significant at the 0.01 level (2-tailed). * Correlation is significant at the 0.05 level (2-tailed). Farming methods: Intensive (factory farm), semi-intensive, and extensive (free range) methods.

Management systems: All-in-all-out, organic, continuous flow barn, breeding, farrow-to-finish, farrow-to-feeder and feeder-to-finish operations.

Regarding the health aspects displayed in Table 3, more than $85 \%$ of farmers vaccinated and dewormed their pigs. Most of the respondents were up to date with their pigs' vaccinations and deworming schedules. This finding was in contrast with the results recorded by Matabane et al (2015), who found that most of the smallholder pig farmers in their study did not vaccinate their pigs. However, almost all $(96.7 \%)$ of the respondents in this study had never taken faecal or blood samples of their pigs or other livestock on their farms for parasitological examination. In addition, $80.4 \%$ of the participants did not employ the services of veterinarians or trained animal health technicians to assist, assess, or treat their herd due to high costs, a lack of availability of these professionals, and accessibility to their farms

Table 3: Responses to pig health related questions

\begin{tabular}{|l|c|c|c|c|}
\hline Factor & Variable & $\begin{array}{c}\text { Response } \\
\text { frequency }\end{array}$ & Percentage (\%) & $\begin{array}{c}\text { Total number of } \\
\text { respondents }\end{array}$ \\
\hline Pig vaccination & Yes & 41 & 89.1 & 46 \\
\hline Up to date vaccination & Yes & 29 & 10.1 & 46 \\
record & No & 10 & 21.7 & \\
\hline Nource of help during & Self & 37 & 80.4 & 46 \\
vaccination & Professional & 9 & 19.6 & 30 \\
\hline Pig deworming & Yes & 28 & 93.3 & 30 \\
\hline Parasitological analyses & No & 2 & 6.7 & 30 \\
of faecal/blood samples & No & 1 & 3.3 & \\
\hline
\end{tabular}


Figure 2 illustrates that $65.2 \%$ of the respondents indicated that there was a problem of intestinal helminths in their pig herd, with parasites (37\%) emerging as the most common herd health problem, followed closely by bacterial diseases (28.3\%). It is noteworthy that $40.4 \%$ of respondents believed that the pigs' environment could be a source of infection, although only $17.4 \%$ cleaned their pig stalls daily, whereas the majority of respondents did not use disinfectants. Across the board, weaners and growers were penned to have the highest infection and mortality rates, with $53.3 \%$ of mortalities occurring in females. In addition, more than half $(53.3 \%)$ of the respondents described the cost of anthelmintics as "expensive".

Figure 3 explains that $78 \%$ of the respondents were not aware of anthelmintic resistance in some porcine helminth species and other livestock nematodes. Reports on anthelmintic resistance in some livestock nematode species of economic importance have been documented in South Africa and other parts of the world (Bakunzi, 2003; Leathwick \& Besier, 2014; Van Den Brom et al, 2015; Van Wyk et al, 1999). Furthermore, 17.4\% of farmers indicated that they repeated or increased the dosage of worm expellers mostly because of anthelmintic failure. In Figure 4, it is seen that the majority of the respondents (88\%) were not aware of the zoonotic nature of porcine helminths, even though $32.6 \%$ claimed they knew how to prevent human infections.

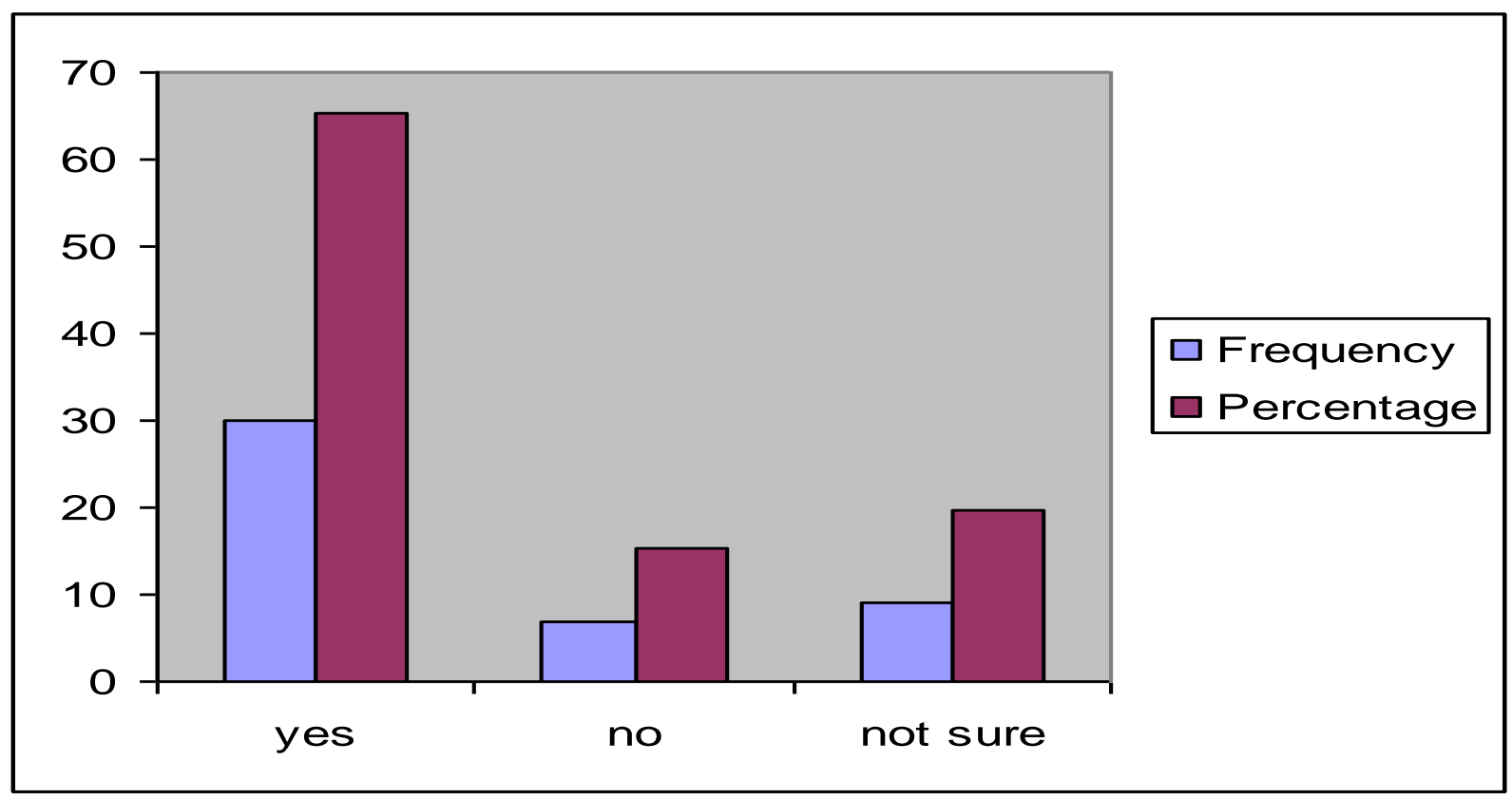

Figure 2: Bar graph illustrating awareness of farmers to porcine helminthiasis 
S. Afr. J. Agric. Ext.

Vol. 47 No. 3, 2019: 61 - 69

http://dx.doi.org/10.17159/2413-3221/2019/v47n3a515

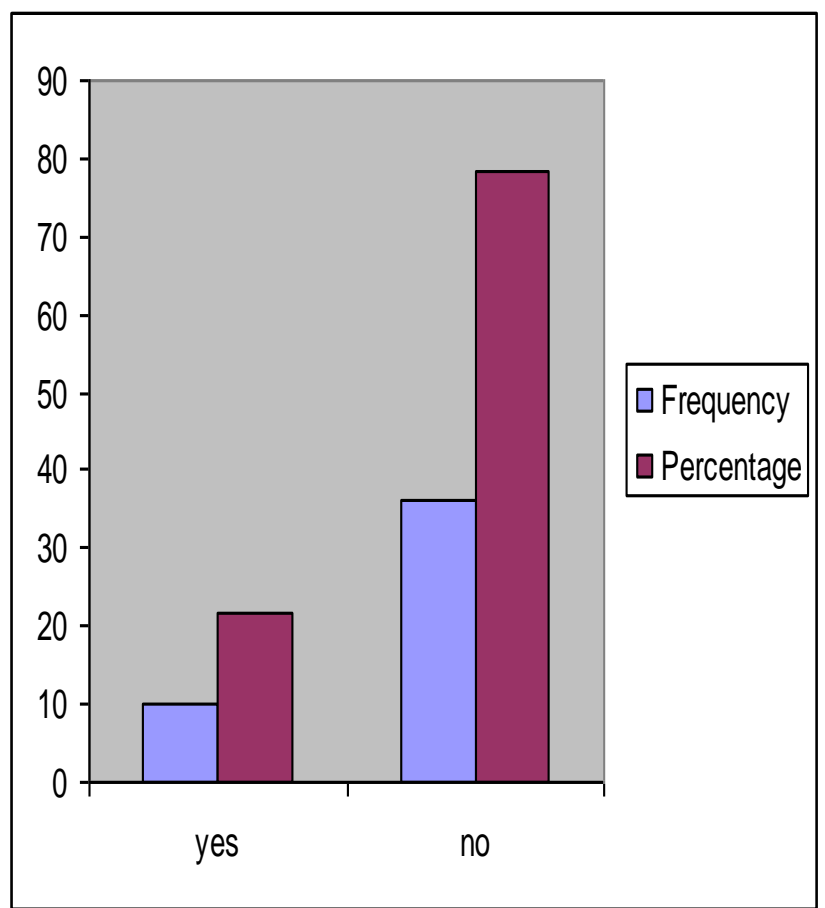

Figure 3: Bar graph illustrating awareness of farmers to anthelmintic resistance

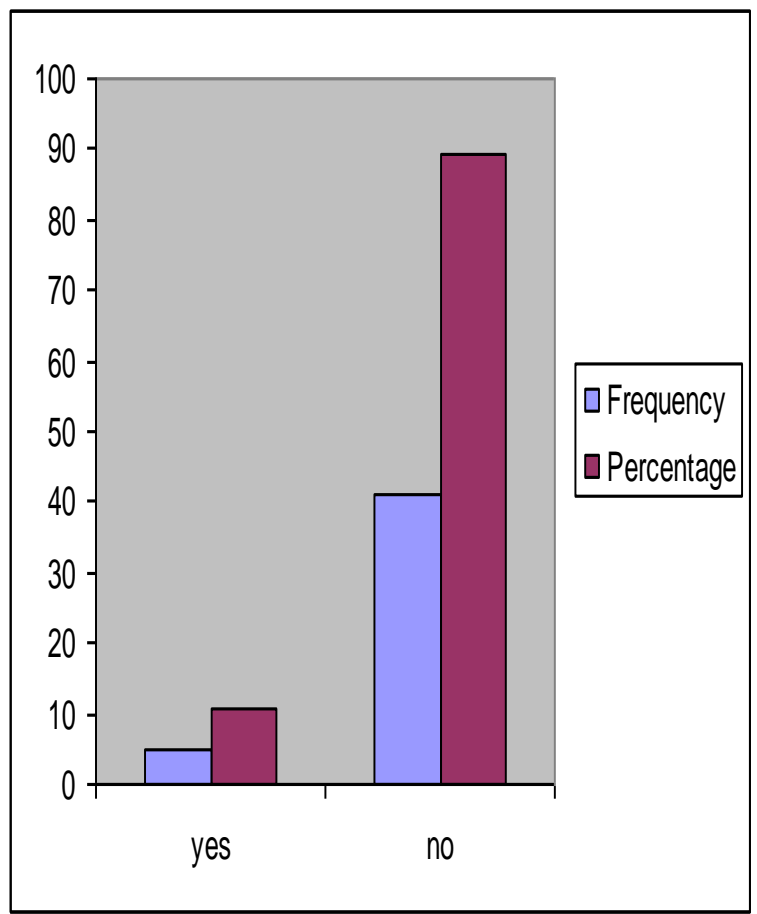

Figure 4: Bar graph illustrating awareness of farmers to zoonosis

Considering the post-slaughter practices, $73.9 \%$ of the respondents did not take their pigs to the abattoir for slaughter. The respondents provided reasons for this which included high cost of slaughter, high cost of transportation, long distances to the abattoir, small scale of production, and very few pigs to slaughter at a given period. All the respondents that made use of the abattoir were mostly satisfied with the sanitary conditions at the abattoir. Amongst the 
few that use abattoirs, $16.7 \%$ of them indicated that their pigs' carcasses have been condemned due to extensive internal infestation by parasites and subsequent organ damage. Of concern, half of the farmers reported that their pig production enterprise was not profitable and therefore not viable.

\section{CONCLUSION AND RECOMMENDATIONS}

It was observed that the smallholder pig farmers in the study area were faced with several constraints that militated against improved pig production and viability. Higher levels of education, periodic training, and monitoring by extension personnel, as well as farmer compliance with relevant guidelines will hopefully be beneficial to productivity and attract young people to the enterprise. More information and government interventions are still required as matters of urgency to increase farmer awareness of the scourge of porcine helminthiasis and to curb the high rate of failed smallholder pig enterprises in the study area. Extension workers, veterinarians and animal health technicians should be mobilised to constantly visit smallholder pig farmers, especially the resource-poor farmers in their operation areas. Farm hygiene compliance should also be periodically monitored. Since prevention is better than cure, farmers should be encouraged to buy "clean" pigs from reputable sources, rear pig breeds that are known to have resistance to intestinal parasites, practise good hygiene and biosecurity, and incorporate multiple sustainable measures to exterminate helminths from their farms. Furthermore, there should be a reduction in over-reliance on chemical strategies to control parasitic infestation due to the associated resistance to them by pig nematodes. Periodically, farmers should send faecal samples of their animals for parasitological examination. This will help to detect the presence of parasites in the herd, the species and infection intensity for effective treatment to follow. More importantly, zoonotic helminth surveillance on smallholder farms and abattoirs should be prioritised by relevant authorities in endemic regions.

\section{ACKNOWLEDGEMENT}

We acknowledge the doctoral research funding from the Central University of Technology for making this project attainable.

\section{REFERENCES}

BAKUNZI, F.R., 2003. Anthelmintic resistance of nematodes in communally grazed goats in a semi-arid area of South Africa. J. S. Afr. Vet. Assoc., 74(3):82-83.

COLES, G.C., JACKSON, F., POMROY, W.E., PRICHARD, R.K., VON SAMSONHIMMELSTJERNA, G., SILVESTRE, A., TAYLOR, M.A. \& VERCRUYSSE, J., 2006. The detection of anthelmintic resistance in nematodes of veterinary importance. Vet. Parasitol., 136(3-4):167-185.

CRESWELL, J.W. \& CRESWELL, J.D., 2003. Research design: Qualitative, quantitative and mixed methods approaches. London: SAGE Publications.

DEPARTMENT OF AGRICULTURE, FORESTRY \& FISHERIES (DAFF), 2012. Abstract of agricultural statistics. Available from: http://www.nda.agric.za/docs/statsinfo/Ab2012.pdf 
EUROPEAN MEDICINES AGENCY (EMA), 2017. Reflection paper on anthelmintic resistance. Available from: https://www.ema.europa.eu/en/documents/scientificguideline/reflection-paper-anthelmintic-resistance_en-1.pdf

KRECEK, R.C., MICHAEL, L.M., WILLINGHAM, A.L. \& SCHANTZ, P.M., 2004. Questionnaire results from a community-based project on porcine cysticercosis in the Eastern Cape Province of South Africa. Southeast Asian J. Trop. Med. Public Health, 35:271-274.

LEATHWICK, D.M. \& BESIER, R.B., 2014. The management of anthelmintic resistance in grazing ruminants in Australasia - Strategies and experiences. Vet. Parasitol., 204(12):44-54.

MAPHALLA, L.T. \& SALMAN, M.V., 2002. Provincial report on education and training for agriculture and rural development: Free State Province. Available from: http://www.nda.agric.za/doaDev/sideMenu/educationAndTraining/Free\%20State.pdf

MATABANE, M.B., NETHENZHENI, P., THOMAS, R., NETSHIROVHA, T., NORRIS, D., NEPHAWE, K.A. \& NEDAMBALE, T.L., 2015. Status of the smallholder pig farming sector in Gauteng Province of South Africa. Appl. Anim. Husb. Rural Develop., 8(1):1925 .

SOUTH AFRICAN GOVERNMENT (SAG), 2015. Agriculture. Available from: http://www.gov.za/about-sa/agriculture

VAN DEN BROM, R., MOLL, L., KAPPERT, C. \& VELLEMA, P., 2015. Haemonchus contortus resistance to monepantel in sheep. Vet. Parasitol., 209(3-4):278-280.

VAN WYK, J.A., MO, S., VAN DER MERWE, J.S. \& VORSTER, R., 1999. Anthelmintic resistance in South Africa: Surveys indicate an extremely serious situation in sheep and goat farming. Onderstepoort J. Vet. Res., 66:273-284. 
